\title{
Correlating physico-mechanical properties of intact rocks with P-wave velocity
}

\author{
C. Kurtuluş $^{1}$ - F. Sertçelik ${ }^{1}$ I. Sertçelik ${ }^{1}$
}

Received: 13 April 2015/Accepted: 9 October 2015/Published online: 19 October 2015

(C) Akadémiai Kiadó 2015

\begin{abstract}
The physico-mechanical properties of five different intact rock types including sandstone, arkoses and limestone were determined through standardized laboratory tests. Ninety six specimens were tested to obtain the relationships between P-wave velocity $\left(\mathrm{V}_{\mathrm{p}}\right)$, dry unit weight (DUW), uniaxial compressive strength (UCS), point load index Is(50), Brazilian tensile strength (TS), porosity $(\Phi)$, and Schmidt hardness (RN). This study also reviews some recent correlations between $\mathrm{P}$-wave velocity and physico-mechanical properties as well as investigates the reliability of these correlations. Findings show the results of the experimental tests are in good agreement with previous studies. Statistical equations have been determined for estimating the physico-mechanical properties of rocks using nondestructive and indirect test methods. Results of regression analysis showed satisfactory correlations. Based on the results, new strong correlation with correlation coeffecients above $\left(\mathrm{R}^{2}>0.80\right)$ are introduced for predicting the UCS, Is $(50), \Phi$ and RN and reasonable good correlations $\left(\mathrm{R}^{2} \geq 0.78\right)$ are introduced to predict TS and DUW from $\mathrm{P}$-wave velocity of different intact rock core samples. There is a discrepancy between $\mathrm{P}$-wave velocity $\left(\mathrm{V}_{\mathrm{p}}\right)$ in situ values with laboratory results. The large reductions in $\mathrm{V}_{\mathrm{p}}$ in situ values are clearly the functions of fractures and natural joints.
\end{abstract}

Keywords Physico-mechanical properties · Kocaeli (Turkey) · P-wave velocity · Dry unit weight $\cdot$ Porosity

F. Sertçelik

fasert@kocaeli.edu.tr

C. Kurtuluş

cengizk@kocaeli.edu.tr

I. Sertçelik

isert@kocaeli.edu.tr

1 Department of Geophysics, Kocaeli University, Kocaeli, Turkey 


\section{Introduction}

Construction of projects such as foundation on rocks, underground structures, infrastructure works, tunnels, dams etc. is substantially influenced by physical and mechanical properties of rocks. The reason of the most of the hazards is the inaccurate evaluation of these rock properties. Especially specimen preparation for laboratory testing to determine the mechanical properties are expensive, difficult to be carried out and time consuming. In addition, the accuracy is mostly dependent on the specimen dimension, human errors, instrument calibration and internal factors. For these difficulties, indirect methods are often applied for preliminary studies. Indirect methods are simple do not require specimen preparation. The physico-mechanical properties of rocks are determined according to both the American Society for Testing and Materials ASTM (1986a) and International Society for Rock Mechanics ISRM (1987) and other common standards.

The P-wave velocity which depends on density and elastic properties of rocks has been used for many years to determine the physico-mechanical properties of different rocks by various authors. Many authors have studied the relations between physicomechanical properties and P-wave velocity of rocks. Smorodinov et al. (1970) established empirical relation between uniaxial compressive strength (UCS) and density/porosity. Inoue and Ohomi (1981) determined the relations between UCS and P-wave velocity of soft rocks. Gaviglio (1989) investigated the relation between P-wave velocity and density. Boadu (2000) found the transport properties of fractured rocks from seismic waves. Kahraman (2001a) made correlations between P-wave velocity and number of joints and Schmidt rebound number (RN). Kahraman (2001b) evaluated the correlations between UCS, point load index (Is(50)), RN, P-wave velocity and impact strength index. Kahraman (2002) estimated the P-wave velocity of intact rock from indirect laboratory measurements. Ozkahraman et al. (2004) obtained the thermal conductivity of rocks from P-wave velocity. Yasar and Erdogan (2004) correlated P-wave velocity with density, Young's modulus and UCS of carbonate rocks. Sharma and Singh (2008) studied on the correlations between the P-wave velocity, impact strength index, slake durability index and UCS. Khandelwal and Singh (2009) correlated the P-wave velocity with different physico-mechanical properties of coal measure rocks. Khandelwal and Ranjith (2010) made correlations of P-wave velocity with index properties of different rock types. Kurtulus et al. (2010) evaluated the physical and mechanical properties of Gokceada: Imbroz (NE AegeanSea) Island andesites. Kurtulus et al. (2011a) studied the physical and mechanical properties of serpentinized ultra basic rocks in NW Turkey. Kurtulus et al. (2011b) studied the seismic anisotropy of Devonian limestone. Empirical relationships proposed in literature between P-wave velocity and uniaxial compressive strength (UCS), point load index $\operatorname{Is}(50)$, porosity $(\Phi)$, Brazilian tensile strength (TS) and Schmidt rebound number (RN) are shown in Table 1. The differences determined could be related to the mineralogical composition and texture of the rock materials or the different methods used for sampling and performing the tests.

This paper aims to evaluate the physico-mechanical properties of intact rocks and the correlation of P-wave velocity with the dry unit weight, uniaxial compressive strength (UCS), Point Load Index (Is(50)), Brazilian Tensile Strength (TS), porosity ( $\Phi)$ and Schmidt Rebound Number ( $\mathrm{RN})$, with the intention of providing detailed documentation about intact rocks. 
Table 1 Equations correlating the UCS, Is(50), $\Phi$, and RN to P-wave velocity for several areas in the world and references

\begin{tabular}{|c|c|c|}
\hline \multicolumn{2}{|l|}{ Equations } & References \\
\hline \multicolumn{2}{|l|}{$\mathrm{UCS}=56.71 \mathrm{~V}_{\mathrm{p}}-192.93$} & Cobanglu and Celik (2008) \\
\hline \multicolumn{3}{|l|}{$\mathrm{UCS}=0.11 \mathrm{~V}_{\mathrm{p}}-515.56$} \\
\hline \multicolumn{2}{|l|}{$\mathrm{UCS}=0.78 \mathrm{e}^{0.88 \mathrm{Vp}}$} & Entwisle et al. (2005) \\
\hline \multicolumn{3}{|l|}{$\mathrm{UCS}=0.78 \mathrm{~V}_{\mathrm{p}}^{0.88}$} \\
\hline \multicolumn{2}{|l|}{$\mathrm{UCS}=9.95 \mathrm{~V}_{\mathrm{p}}^{1.21}$} & Kahraman (2001b) \\
\hline \multicolumn{2}{|l|}{$\mathrm{UCS}=0.133 \mathrm{~V}_{\mathrm{p}}-227.19$} & Khandelwal and Singh (2009) \\
\hline \multicolumn{2}{|l|}{$\rho=0.0002(\mathrm{UPV})+1.8745$} & Kurtulus et al. (2010) \\
\hline \multicolumn{3}{|l|}{$\mathrm{Is}(50)=0.0018(\mathrm{UPV})-1.9906$} \\
\hline \multicolumn{3}{|l|}{$\mathrm{UCS}=0.1581(\mathrm{UPV})-643.2$} \\
\hline \multicolumn{3}{|l|}{$\mathrm{RN}=0.0319(\mathrm{UPV})-92.442$} \\
\hline \multicolumn{3}{|l|}{$\mathrm{n}=-6.10-0.5(\mathrm{UPV})+0.0366$} \\
\hline $\mathrm{UCS}=0.0675(\mathrm{UPV})-245.13$ & Across foliation & Kurtulus et al. (2011a) \\
\hline $\operatorname{Is}(50)=0.0042(\mathrm{UPV})-14.602$ & ‘' & \\
\hline $\mathrm{DUW}=0.0002(\mathrm{UPV})+1.7752$ & ‘ & \\
\hline $\mathrm{n}=-0.0031(\mathrm{UPV})+16.736$ & ‘' & \\
\hline $\mathrm{UCS}=0.0188(\mathrm{UPV})-71.04$ & Along foliation & \\
\hline $\mathrm{Is}(50)=0.0013(\mathrm{UPV})-4.819$ & ‘' & \\
\hline $\mathrm{DUW}=0.0001(\mathrm{UPV})+1.7937$ & ‘ & \\
\hline $\mathrm{n}=-0.0029(\mathrm{UPV})+16.733$ & “' & \\
\hline $\operatorname{Is}(50)=0.0033(\mathrm{UPV})-7.7876$ & Across foliation & Kurtulus et al. (2011b) \\
\hline $\mathrm{UCS}=0.0533(\mathrm{UPV})-1326.29$ & “' & \\
\hline $\mathrm{n}=-0.0011(\mathrm{UPV})+5.6858$ & ‘, & \\
\hline $\mathrm{d}=0.0002(\mathrm{UPV})+1.6769$ & “' & \\
\hline $\mathrm{Is}(50)=0.0016(\mathrm{UPV})-2.4235$ & Along foliation & \\
\hline $\mathrm{UCS}=0.0207(\mathrm{UPV})-24.729$ & ‘, & \\
\hline $\mathrm{n}=-0.0005(\mathrm{UPV})-3.3089$ & ‘' & \\
\hline $\mathrm{d}=8 \mathrm{E}-05(\mathrm{UPV})+2.0858$ & ‘' & \\
\hline $\mathrm{UCS}=165.05 \mathrm{e}^{(-4.452 / \mathrm{v})} \mathrm{p}$ & & Moradian and Behnia (2009) \\
\hline $\mathrm{UCS}=0.0642 \mathrm{~V}_{\mathrm{p}}-117.99$ & & Sharma and Singh (2008) \\
\hline $\mathrm{SV}=4.3183 .9 \rho-7.5071$ & & Yasar and Erdogan (2004) \\
\hline
\end{tabular}

Where $\left(V_{p}\right.$ and $\left.S V\right)$ P-wave velocity, $(D U W, d, \rho)$ dry unit weight, (UCS) uniaxial compressive strength, $I s(50)$ point load index, $(\Phi, n)$ porosity, $(R N, S C H)$ Schmidt rebound number

\section{Research methodology}

\subsection{Sample collection}

The rock samples were collected from five areas in Kocaeli area (Fig. 1).

Laboratory tests were performed on 96 rock specimens, including 10 of which are volcanic and 86 of them are sedimentary rocks (Table 2). 


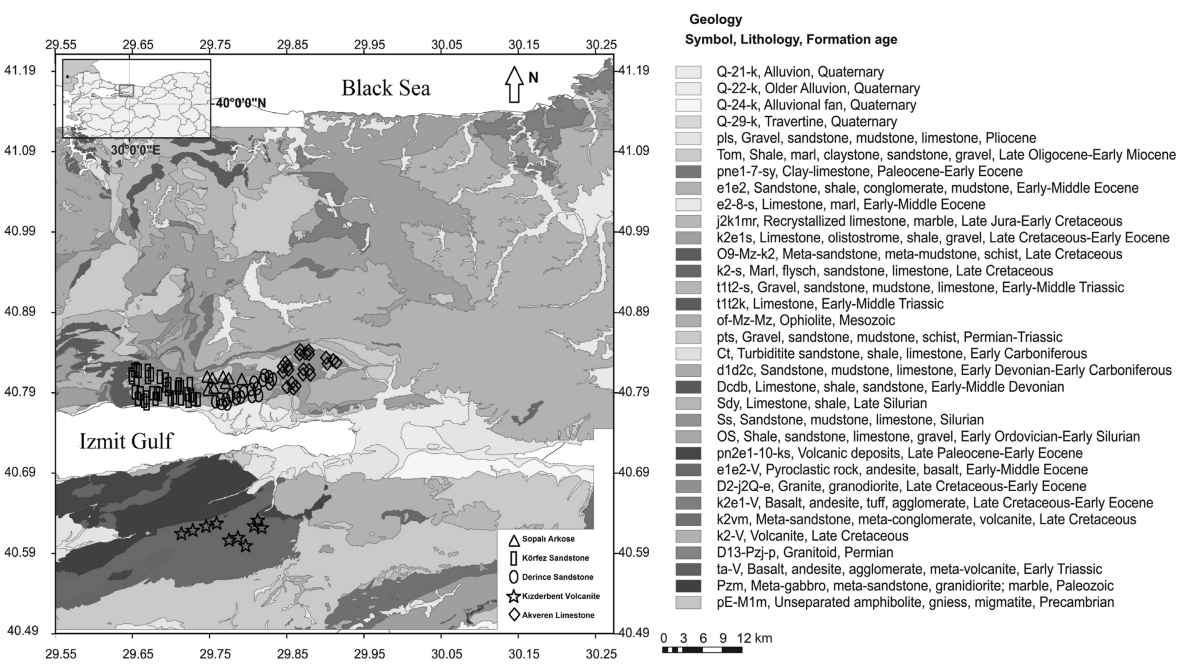

Fig. 1 Geology map of the research area (TUBITAK 2010). K1zderbent Volcanic, Sopalı Arkose, Körfez Sandstone, Derince Sandstone and Akveren Limestone specimens are shown by the star, circle, rectangle, triangle and square, respectively

Table 2 List of rock types with class and location

\begin{tabular}{lcll}
\hline Rock type & No of specimen & Rock class & Lithologic age \\
\hline Kizderbent volcanic & 10 & Igneous & Lower-middle Eocene \\
Sopalı Arkose & 8 & Sedimentary & Silurian \\
Körfez sandstone & 36 & Sedimentary & Lower Ordovician-lower Silurian \\
Derince sandstone & 20 & Sedimentary & Lower Ordovician-lower Silurian \\
Akveren limestone & 22 & Sedimentary & Upper Cretaceous-lower Eocene \\
\hline
\end{tabular}

\subsection{Laboratory investigation}

Core specimens of rock samples collected from five different rock types were cored in NX size (54 mm diameter) by coring machine. The both ends of the specimens were trimmed as 110-115 cm (ISRM 1981) and smoothed using a lathe to avoid end effects. The specimens were dried at $105{ }^{\circ} \mathrm{C}$ for $24 \mathrm{~h}$ to remove moisture because drying of the specimens are particularly important not to damage or alter the rock fabric. In addition, dry weights are absolutely crucial and must be well defined, stable and controlled throughout handling before, during and after analysis.

\subsection{Determination of $\mathbf{P}$-wave velocity}

The P-wave velocity of rock specimens was determined using Pundit Plus with the transducers having a 54.0 KHZ frequency as per the ISRM (ASTM 2001; ISRM 2007). Figure 2 shows ultrasonic pulse testers used in this study. A mechanical pulses generated by this instrument are transmitted from one end received at another end of the specimens by piezo-electric transducers. The velocity is determined by dividing the traveling the distance (d) to travel time elapsed (t) in traveling the distance by the wave pulse from the emitter to receiver placed both ends of the specimens, Table 3. 
Fig. 2 Ultrasonic pulse tester instruments

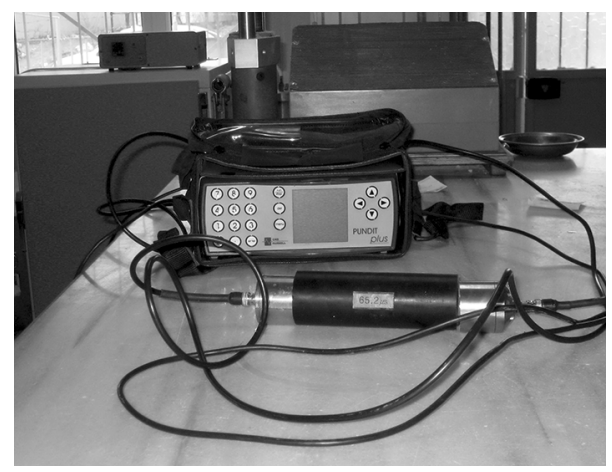

As seen from Table 3, the velocity of Kizderbent volcanite specimens ranges from 5800.0 to $6340.0 \mathrm{~m} / \mathrm{s}$ with the mean $6370.0 \mathrm{~m} / \mathrm{s}$, whereas that of Sopal1 arkose specimens vary between 2544.0 and $3300.0 \mathrm{~m} / \mathrm{s}$ with the mean $2922.0 \mathrm{~m} / \mathrm{s}$. The velocity of Körfez sandstone specimens change between 2968.0 and $6010.0 \mathrm{~m} / \mathrm{s}$ with the mean $4489.0 \mathrm{~m} / \mathrm{s}$ and that of Akveren limestone specimens ranges from 4300.0 and $5800.0 \mathrm{~m} / \mathrm{s}$ with the mean $5050.0 \mathrm{~m} / \mathrm{s}$. The velocity of Derince sandstone specimens vary between 1890.0 and $3300.0 \mathrm{~m} / \mathrm{s}$ with the mean $2595.0 \mathrm{~m} / \mathrm{s}$.

\subsection{Determination of different physico-mechanical properties}

The effective porosity of rock specimens were determined using saturation method. Dry unit weights and effective porosity of the rock specimens were determined in accordance with ISRM (2007). The uniaxial compressive strength (UCS) were obtained by subjecting each specimen to $\mathrm{H}$ incremental loading at about constant rate using a hydraulic testing machine of $150.0 \mathrm{KN}$ capacity in accordance with ASTM (1986b). The Is (50) of the specimens was determined by mounting each specimen between two platens of a point load tester of 50.0 KN capacities in accordance with ASTM (2005). Schmidt hardness of the specimens was determined according to ASTM D5873 (2014) standard recommendations on cylindrical specimens using a Schmidt hammer type NR of impact energy of 2.207 Nm. The Brazilian tensile strength of the specimens of NX diameter were determined using Brazilian test apparatus equipped with digital display unit for displaying maximum load. Rock specimens were loaded diametrically between the loading platens of the apparatus as per ISRM (1978) standards.

\subsection{Geophysical survey}

The seismic refraction surveys were conducted at K1zderbent volcanites, Sopal1 Arkose, Körfez sandstone, Akveren limestone and Derince sandstone in the investigation area to correlate the ultrasonic pulse velocities of rock specimens with dynamic P-wave velocities. The seismic refraction data were recorded using a 12 channel Geometrics Seismic Enhancement (Smart Seis) seismograph. The first arrival phases assumed to be refracted from the same interface, the P-wave velocities were calculated from the slope of the line connecting the first arrival phases using GeoSeis computer program. The determined average P-velocities are given in Table 4.

The discrepancy increases notably when comparing $V_{p}$ in situ values with laboratory results. The large reductions in $V_{p}$ in situ values are clearly the functions of fractures and 
Table $3 \mathrm{~V}_{\mathrm{p}}$, DUW, UCS, Is(50), TS, $\Phi$, and RN test results

\begin{tabular}{|c|c|c|c|c|c|c|c|}
\hline B & $\begin{array}{l}\text { DUW } \\
\left(\mathrm{g} / \mathrm{cm}^{3}\right)\end{array}$ & UCS (MPa) & $\mathrm{Is}(50)(\mathrm{MPa})$ & TS (MPa) & $\Phi(\%)$ & $\mathrm{RN}$ & Formation \\
\hline 5800 & 2.68 & 172.0 & 13.5 & 57.0 & 0.048 & 51.0 & Kizderbent volcanites \\
\hline 5910 & 2.77 & 177.0 & 14.3 & 60.0 & 0.045 & 52.0 & Kizderbent volcanites \\
\hline 5957 & 2.78 & 184.0 & 13.46 & 62.0 & 0.04 & 53.0 & Kizderbent volcanites \\
\hline 6150 & 2.82 & 189.0 & 14.68 & 63.5 & 0.038 & 56.0 & Kizderbent volcanites \\
\hline 6245 & 2.89 & 198.0 & 15.23 & 65.0 & 0.034 & 58.0 & K1zderbent volcanites \\
\hline 6274 & 2.85 & 198.0 & 16.2 & 60.0 & 0.034 & 55.0 & K1zderbent volcanites \\
\hline 6185 & 2.88 & 185.0 & 15.36 & 59.0 & 0.041 & 55.0 & K1zderbent volcanites \\
\hline 6318 & 2.9 & 199.0 & 15.9 & 61.0 & 0.033 & 57.0 & Kizderbent volcanites \\
\hline 6324 & 2.84 & 195.0 & 15.8 & 53.0 & 0.035 & 56.0 & Kızderbent volcanites \\
\hline 6340 & 2.95 & 202.0 & 16.32 & 62.0 & 0.032 & 60.0 & Kizderbent volcanites \\
\hline 3153 & 2.43 & 18.0 & 1.86 & 29.0 & 0.278 & 32.0 & Sopalı Arkose \\
\hline 3159 & 2.38 & 18.0 & 1.76 & 25.0 & 0.276 & 32.0 & Sopalı Arkose \\
\hline 2544 & 2.31 & 11.6 & 0.93 & 29.0 & 0.24 & 24.0 & Sopalı Arkose \\
\hline 3160 & 2.32 & 23.5 & 1.88 & 35.0 & 0.249 & 32.0 & Sopalı Arkose \\
\hline 2668 & 2.25 & 12.35 & 1.13 & 23.0 & 0.26 & 29.0 & Sopalı Arkose \\
\hline 2918 & 2.18 & 15.375 & 1.23 & 33.0 & 0.23 & 31.0 & Sopalı Arkose \\
\hline 3255 & 2.51 & 23.5 & 2.1 & 38.0 & 0.25 & 32.0 & Sopalı Arkose \\
\hline 3300 & 2.46 & 28.0 & 2.24 & 38.0 & 0.23 & 32.0 & Sopalı Arkose \\
\hline 5150 & 2.63 & 102.34 & 8.19 & 55.0 & 0.1 & 49.0 & Körfez sandstone \\
\hline 4968 & 2.58 & 119.32 & 9.55 & 45.0 & 0.085 & 35.0 & Körfez sandstone \\
\hline 3874 & 2.25 & 59.52 & 4.76 & 37.0 & 0.156 & 35.0 & Körfez sandstone \\
\hline 6010 & 2.89 & 164.34 & 13.15 & 58.0 & 0.058 & 54.0 & Körfez sandstone \\
\hline 5246 & 2.66 & 126.34 & 10.11 & 55.0 & 0.079 & 44.0 & Körfez sandstone \\
\hline 4870 & 2.55 & 100.45 & 8.04 & 41.0 & 0.1 & 41.0 & Körfez sandstone \\
\hline 4338 & 2.39 & 101.32 & 8.11 & 39.0 & 0.1 & 35.0 & Körfez sandstone \\
\hline 3200 & 2.05 & 46.75 & 3.74 & 37.0 & 0.18 & 34.0 & Körfez sandstone \\
\hline 3345 & 2.09 & 52.37 & 4.19 & 40.0 & 0.17 & 34.0 & Körfez sandstone \\
\hline 2968 & 1.98 & 53.96 & 4.32 & 22.0 & 0.165 & 34.0 & Körfez sandstone \\
\hline 3610 & 2.17 & 73.65 & 5.89 & 30.0 & 0.14 & 34.0 & Körfez sandstone \\
\hline 4535 & 2.45 & 89.33 & 7.14 & 40.0 & 0.11 & 35.0 & Körfez sandstone \\
\hline 4380 & 2.4 & 89.63 & 7.17 & 51.0 & 0.113 & 35.0 & Körfez sandstone \\
\hline 3800 & 2.23 & 82.55 & 6.6 & 33.0 & 0.12 & 34.0 & Körfez sandstone \\
\hline 5380 & 2.7 & 127.45 & 10.2 & 50.0 & 0.078 & 35.0 & Körfez sandstone \\
\hline 4925 & 2.66 & 117.44 & 9.4 & 35.0 & 0.086 & 35.0 & Körfez sandstone \\
\hline 4360 & 2.4 & 84.86 & 6.79 & 30.0 & 0.12 & 35.0 & Körfez sandstone \\
\hline 3990 & 2.29 & 86.79 & 6.94 & 48.0 & 0.12 & 41.0 & Körfez sandstone \\
\hline 2950 & 1.97 & 55.32 & 4.43 & 24.0 & 0.16 & 34.0 & Körfez sandstone \\
\hline 4640 & 2.48 & 98.35 & 7.87 & 37.0 & 0.1 & 35.0 & Körfez sandstone \\
\hline 4409 & 2.52 & 37.69 & 3.67 & 48.0 & 0.18 & 41.0 & Körfez sandstone \\
\hline 4667 & 2.54 & 72.0 & 3.66 & 51.0 & 0.14 & 47.0 & Körfez sandstone \\
\hline 5455 & 2.61 & 135.0 & 12.2 & 50.0 & 0.073 & 49.0 & Körfez sandstone \\
\hline 5070 & 2.62 & 129.0 & 11.5 & 57.0 & 0.077 & 50.0 & Körfez sandstone \\
\hline 4876 & 2.56 & 99.0 & 3.98 & 44.0 & 0.1 & 39.0 & Körfez sandstone \\
\hline
\end{tabular}


Table 3 continued

\begin{tabular}{|c|c|c|c|c|c|c|c|}
\hline B & $\begin{array}{l}\text { DUW } \\
\left(\mathrm{g} / \mathrm{cm}^{3}\right)\end{array}$ & UCS (MPa) & Is (50) (MPa) & TS (MPa) & $\Phi(\%)$ & $\mathrm{RN}$ & Formation \\
\hline 4964 & 2.56 & 116.0 & 7.2 & 45.0 & 0.088 & 40.0 & Körfez sandstone \\
\hline 4746 & 2.55 & 127.0 & 7.7 & 56.0 & 0.078 & 41.0 & Körfez sandstone \\
\hline 4680 & 2.55 & 82.0 & 3.9 & 49.0 & 0.12 & 39.0 & Körfez sandstone \\
\hline 4576 & 2.54 & 80.0 & 3.24 & 44.0 & 0.125 & 33.0 & Körfez sandstone \\
\hline 4943 & 2.58 & 96.0 & 7.8 & 42.0 & 0.1 & 40.0 & Körfez sandstone \\
\hline 4595 & 2.53 & 82.0 & 3.73 & 48.0 & 0.12 & 38.0 & Körfez sandstone \\
\hline 4560 & 2.55 & 91.0 & 3.55 & 44.0 & 0.11 & 38.0 & Körfez sandstone \\
\hline 4826 & 2.55 & 111.0 & 7.3 & 55.0 & 0.092 & 45.0 & Körfez sandstone \\
\hline 4799 & 2.57 & 87.0 & 5.7 & 57.0 & 0.12 & 40.0 & Körfez sandstone \\
\hline 5160 & 2.83 & 70.0 & 6.8 & 59.0 & 0.14 & 51.0 & Körfez sandstone \\
\hline 5146 & 2.55 & 79.0 & 8.5 & 60.0 & 0.13 & 48.0 & Körfez sandstone \\
\hline 5300 & 2.4 & 126.0 & 9.6 & 55.0 & 0.08 & 51.0 & Akveren limestone \\
\hline 5100 & 2.21 & 118.0 & 10.4 & 38.0 & 0.086 & 51.0 & Akveren limestone \\
\hline 4900 & 2.3 & 102.0 & 9.7 & 36.0 & 0.1 & 35.0 & Akveren limestone \\
\hline 5600 & 2.55 & 140.0 & 11.4 & 48.0 & 0.069 & 53.0 & Akveren limestone \\
\hline 4400 & 2.2 & 28.0 & 7.4 & 35.0 & 0.23 & 41.0 & Akveren limestone \\
\hline 5500 & 2.43 & 118.0 & 13.2 & 41.0 & 0.086 & 55.0 & Akveren limestone \\
\hline 5500 & 2.5 & 132.0 & 14.2 & 43.0 & 0.074 & 54.0 & Akveren limestone \\
\hline 4800 & 2.1 & 160.0 & 11.3 & 56.0 & 0.055 & 40.0 & Akveren limestone \\
\hline 5200 & 2.44 & 36.0 & 13.6 & 55.0 & 0.2 & 44.0 & Akveren limestone \\
\hline 5200 & 2.54 & 138.0 & 12.3 & 53.0 & 0.07 & 40.0 & Akveren limestone \\
\hline 5200 & 2.45 & 142.0 & 11.6 & 56.0 & 0.067 & 38.0 & Akveren limestone \\
\hline 5200 & 2.41 & 110.0 & 12.2 & 49.0 & 0.09 & 40.0 & Akveren limestone \\
\hline 5200 & 2.46 & 122.0 & 11.5 & 43.0 & 0.08 & 38.0 & Akveren limestone \\
\hline 5200 & 2.43 & 128.0 & 12.2 & 53.0 & 0.078 & 36.0 & Akveren limestone \\
\hline 4300 & 2.11 & 88.0 & 5.2 & 40.0 & 0.012 & 41.0 & Akveren limestone \\
\hline 5800 & 2.6 & 127.0 & 12.6 & 53.0 & 0.079 & 53.0 & Akveren limestone \\
\hline 5200 & 2.54 & 115.0 & 11.5 & 58.0 & 0.089 & 38.0 & Akveren limestone \\
\hline 4900 & 2.78 & 89.0 & 10.3 & 42.0 & 0.11 & 48.0 & Akveren limestone \\
\hline 4800 & 2.74 & 82.0 & 8.3 & 40.0 & 0.12 & 45.0 & Akveren limestone \\
\hline 5600 & 2.55 & 110.0 & 7.2 & 51.0 & 0.093 & 45.0 & Akveren limestone \\
\hline 5100 & 2.43 & 98.0 & 6.6 & 54.0 & 0.1 & 45.0 & Akveren limestone \\
\hline 4800 & 2.44 & 92.0 & 8.8 & 44.0 & 0.11 & 45.0 & Akveren limestone \\
\hline 2210 & 1.68 & 13.86 & 1.11 & 27.0 & 0.29 & 23.0 & Derince sandstone \\
\hline 2100 & 1.57 & 10.69 & 0.86 & 23.0 & 0.26 & 29.0 & Derince sandstone \\
\hline 1890 & 1.66 & 9.65 & 0.77 & 15.0 & 0.31 & 23.0 & Derince sandstone \\
\hline 2400 & 1.9 & 18.5 & 1.48 & 28.0 & 0.27 & 29.0 & Derince sandstone \\
\hline 2365 & 1.87 & 18.42 & 1.47 & 21.0 & 0.21 & 27.0 & Derince sandstone \\
\hline 2390 & 1.92 & 19.17 & 1.53 & 27.0 & 0.23 & 25.0 & Derince sandstone \\
\hline 2340 & 1.68 & 14.55 & 1.64 & 32.0 & 0.21 & 29.0 & Derince sandstone \\
\hline 2580 & 1.69 & 22.48 & 1.8 & 30.0 & 0.25 & 32.0 & Derince sandstone \\
\hline 2389 & 1.55 & 20.68 & 1.65 & 28.0 & 0.26 & 27.0 & Derince sandstone \\
\hline 2725 & 1.8 & 26.86 & 2.15 & 32.0 & 0.28 & 31.0 & Derince sandstone \\
\hline
\end{tabular}


Table 3 continued

\begin{tabular}{llllllll}
\hline B & $\begin{array}{l}\text { DUW } \\
\left(\mathrm{g} / \mathrm{cm}^{3}\right)\end{array}$ & UCS $(\mathrm{MPa})$ & Is(50) $(\mathrm{MPa})$ & TS $(\mathrm{MPa})$ & $\Phi(\%)$ & RN & Formation \\
\hline 2640 & 1.72 & 24.64 & 1.97 & 36.0 & 0.19 & 29.0 & Derince sandstone \\
3145 & 1.82 & 32.65 & 2.61 & 38.0 & 0.22 & 33.0 & Derince sandstone \\
3050 & 1.69 & 30.69 & 2.46 & 31.0 & 0.22 & 29.0 & Derince sandstone \\
2480 & 1.68 & 19.66 & 1.58 & 20.0 & 0.24 & 25.0 & Derince sandstone \\
2590 & 1.87 & 23.55 & 1.88 & 27.0 & 0.21 & 32.0 & Derince sandstone \\
2867 & 1.86 & 27.45 & 2.2 & 33.0 & 0.23 & 29.0 & Derince sandstone \\
3100 & 1.92 & 31.65 & 2.53 & 35.0 & 0.22 & 27.0 & Derince sandstone \\
2462 & 1.76 & 21.18 & 1.69 & 16.0 & 0.26 & 21.0 & Derince sandstone \\
2380 & 1.8 & 19.66 & 1.57 & 25.0 & 0.23 & 22.0 & Derince sandstone \\
3268 & 1.96 & 33.54 & 1.68 & 33.0 & 0.21 & 38.0 & Derince sandstone \\
\hline
\end{tabular}

Table 4 Average P-wave velocities of rocks obtained from seismic refraction surveys in the investigation areas

\begin{tabular}{ll}
\hline Investigation area & Average P-wave velocity $(\mathrm{m} / \mathrm{s})$ \\
\hline Kizderbent volcanites & 4560.0 \\
Sopalı Arkoz & 1500.0 \\
Körfez sandstone & 1701.0 \\
Akveren limestone & 1483.0 \\
Derince sandstone & 1493.0 \\
\hline
\end{tabular}

natural joints. P-wave velocity depends on mineralogical composition, micro cracks and pores of the rocks and on the physical parameters, such as absorption by weight, density or porosity.

\subsection{Result and discussion}

Results of laboratory tests on 96 specimens are listed in Table 3. As can be seen in this table, volcanic rocks give higher uniaxial compressive strength (UCS) values (172-202 MPa) and point load index Is(50) compared to sedimentary rocks.

The previous literatures show that our results are in acceptable ranges (Cobanglu and Celik 2008; Entwisle et al. 2005; Kahraman 2001a; Khandelwal and Singh 2009; Kurtulus et al. 2010; Kurtulus et al. 2011a; Kurtulus et al. 2011b; Moradian and Behnia 2009; Sharma and Singh 2008).

In order to describe the relationships between P-wave velocity and physico-mechanical properties of rocks a regression analysis was carried out. The equation of the best fit line and the coefficient of determination $\left(\mathrm{R}^{2}\right)$ were determined for each test result (Figs. 3, 4, 5, $6,7,8)$. It can be seen from the figures that, in all cases, the best fit relationships were found to be the best.

There is an exponential relation between P-wave velocity and dry unit weight with a strong correlation of $\left(\mathrm{R}^{2}=0.795\right)$ (Fig. 3). The equation of this relation is given as;

$$
\mathrm{DUW}=0.52 \mathrm{~V}_{\mathrm{p}}^{0.45} \quad\left(\mathrm{R}^{2}=0.795\right)
$$




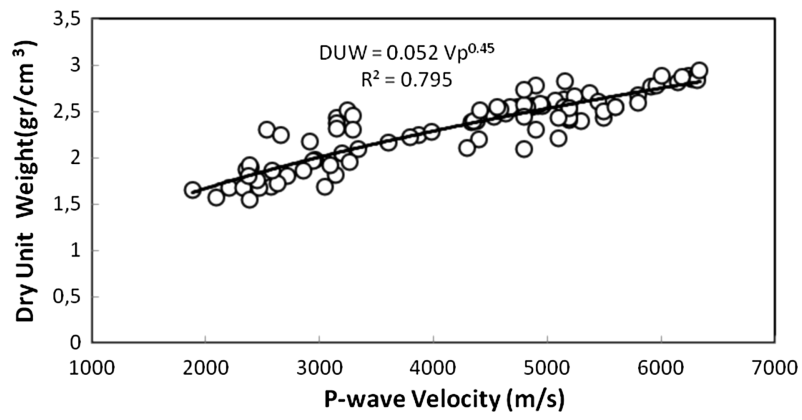

Fig. 3 Graph of dry unit weight (DUW) and P-wave velocity $\left(\mathrm{V}_{\mathrm{p}}\right)$

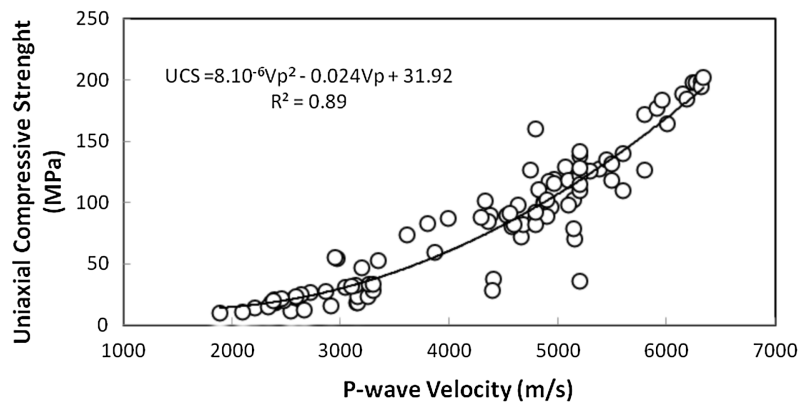

Fig. 4 Graph of uniaxial compressive strength (UCS) and P-wave velocity $\left(\mathrm{V}_{\mathrm{p}}\right)$

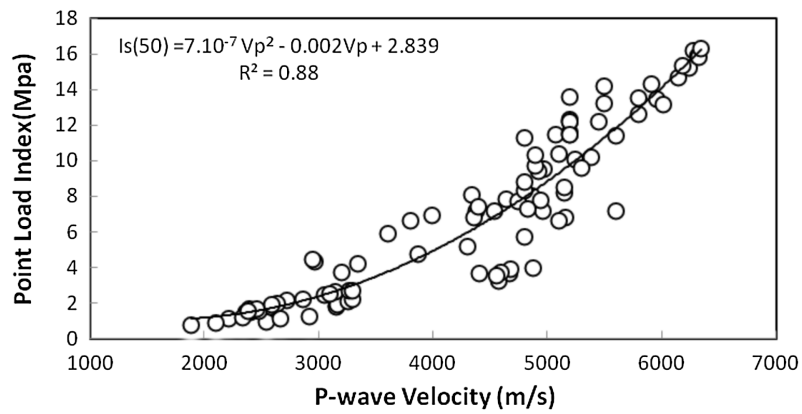

Fig. 5 Graph of point load index $(\operatorname{Is}(50))$ and P-wave velocity $\left(\mathrm{V}_{\mathrm{p}}\right)$

Polynomial relations have been observed between P-wave velocity and UCS and Is(50) (Figs. 4, 5). The equations are given below:

$$
\begin{array}{cc}
\mathrm{UCS}=8.10^{-6} \mathrm{Vp}^{2}-0.024 \mathrm{Vp}+31.92 & \left(\mathrm{R}^{2}=0.89\right) \\
\mathrm{I}_{\mathrm{S}}(50)=7.10^{-7} \mathrm{~V}_{\mathrm{p}}^{2}-0.002 \mathrm{~V}_{\mathrm{p}}+2.839 & \left(\mathrm{R}^{2}=0.88\right)
\end{array}
$$

A very good correlation $\left(\mathrm{R}^{2}=0.89\right)$ was found between $\mathrm{V}_{\mathrm{p}}$ and $\mathrm{UCS}$, and also $\left(\mathrm{R}^{2}=0.88\right)$ between $\mathrm{V}_{\mathrm{p}}$ and $\mathrm{Is}(50)$ for P-wave velocity and the tensile strength, effective porosity and Schmidt rebound number show linear relationships (Figs. 6, 7, 8). 


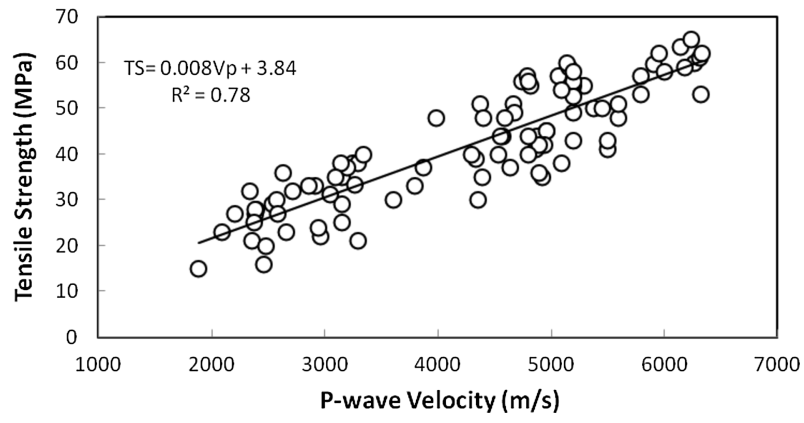

Fig. 6 Graph of tensile strength (TS) and P-wave velocity $\left(\mathrm{V}_{\mathrm{p}}\right)$

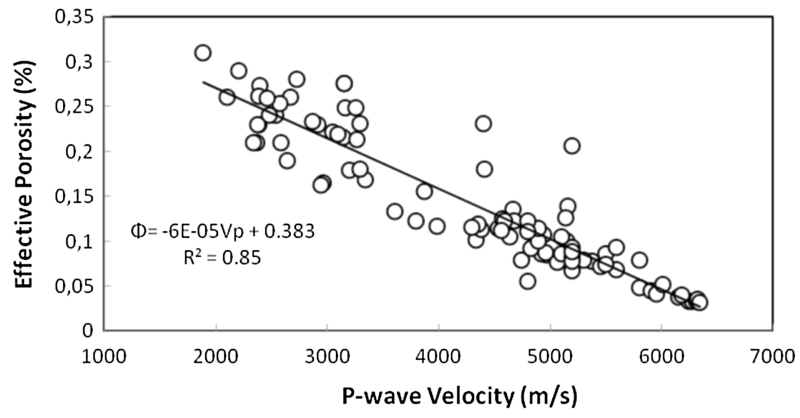

Fig. 7 Graph of effective porosity $(\Phi)$ and P-wave velocity $\left(\mathrm{V}_{\mathrm{p}}\right)$

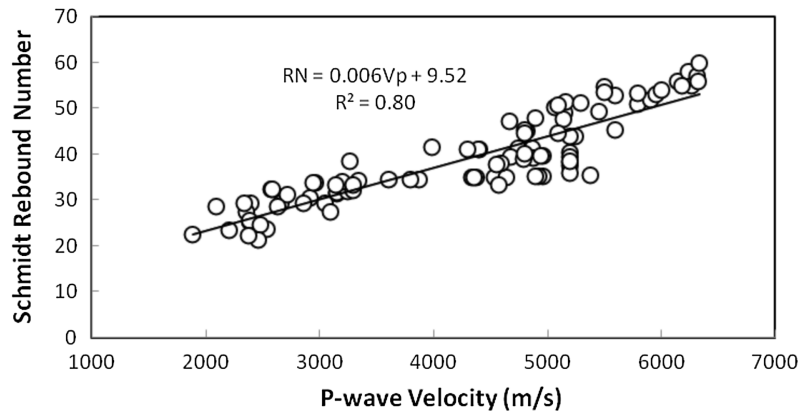

Fig. 8 Graph of Schmidt rebound number $(\mathrm{RN})$ and P-wave velocity $\left(\mathrm{V}_{\mathrm{p}}\right)$

$$
\begin{array}{cc}
\mathrm{TS}=0.008 \mathrm{~V}_{\mathrm{p}}+3.84 & \left(\mathrm{R}^{2}=0.78\right) \\
\varnothing=-6 \mathrm{E}-05 \mathrm{~V}_{\mathrm{p}}+0.383 & \left(\mathrm{R}^{2}=0.85\right) \\
\mathrm{RN}=0.006 \mathrm{~V}_{\mathrm{p}}+9.52 & \left(\mathrm{R}^{2}=0.80\right)
\end{array}
$$

A good correlation $\left(\mathrm{R}^{2}=0.78\right)$ was found between $\mathrm{P}$-wave velocity and Brazilian tensile strength, $\left(R^{2}=0.85\right)$ between $V_{p}$ and $\varnothing$, and $\left(R^{2}=0.80\right)$ between $V_{p}$ and $R N$. 
From Fig. 7, it may be seen that when, the P- wave velocity increases the porosity decreases. However, from Figs. 3, 4, 5, 6, and 8 it can be observed that when the Pwave velocity increases, dry unit weight, uniaxial compressive strength, point load index, tensile strength and Schmidt rebound number increase. Kizderbent volcanites have the highest P-wave velocities range between 5800.0 and $6340.0 \mathrm{~m} / \mathrm{s}$ with the mean $6370.0 \mathrm{~m} / \mathrm{s}$ and for physico-mechanical properties wherein dry unit weights (DUW) vary between 2.68 and $2.95 \mathrm{gr} / \mathrm{cm}^{3}$ with the mean $2.815 \mathrm{gr} / \mathrm{cm}^{3}$, uniaxial compressive strengths (UCS) range from 172.0 to $202.0 \mathrm{MPa}$ with the mean 187.0 MPa, Point load index (Is (50)) change between 13.6 and 16.32 MPa with the mean 14.96 MPa, Brazilian tensile strengths range between 53.0 and $65.0 \mathrm{MPa}$ with the mean 59.0 MPa and Schmidt rebound numbers vary from 51.0 to 60.0 with the mean 55.5. K1zderbent volcanites have the lowest effective porosity values $(\Phi)$ vary between 0.032 and $0.048 \%$ with the mean $0.04 \%$. Sopal1 Arkoses have the lowest P-wave velocities ranging from 2544.0 to $3300.0 \mathrm{~m} / \mathrm{s}$ with the mean $2922.0 \mathrm{~m} / \mathrm{s}$. Their (DUW) vary between 2.18 and $2.46 \mathrm{gr} / \mathrm{cm}^{3}$ with the mean $2.32 \mathrm{gr} / \mathrm{cm}^{3}$, (UCS) range between 11.6 and $28 \mathrm{MPa}$ with the mean $19.8 \mathrm{MPa}$, (Is (50)) change between 0.93 and $2.24 \mathrm{MPa}$ with the mean $1.585 \mathrm{MPa}$, (TS) range from 25.0 to $38.0 \mathrm{MPa}$ with the mean $31.5 \mathrm{MPa}$, $(\mathrm{RN})$ change between 24.0 and 32.0 with the mean 28.0. Sopali arkoses have the highest effective porosities $(\Phi)$ vary between 0.23 and $0.278 \%$ with the mean $0.254 \%$. P-wave velocities and physicomechanical properties of Körfez sandstone, Akveren limestone and Derince sandstone follow the Kizderbent volcanites respectively. In general, the correlation coefficients $\left(\mathrm{R}^{2}\right)$ were lower for the DUW and TS than for the UCS, Is (50), $\Phi$ and RN (Figs. 3, 4, 5, 6, 7, 8 ) in this study.

The relation between DUW and $\mathrm{V}_{\mathrm{p}}$ is similar to relationship given by Kurtulus et al. (2011b), but its correlation coefficient $\left(\mathrm{R}^{2}=0.795\right)$ higher than proposed by Kurtulus et al. (2011b). The proposed relationship between UCS and $V_{p}$ is similar to suggested relationships given by Cobanglu and Celik (2008) and Kurtulus et al. (2010), but correlation coefficient is 0.89 which is relatively higher than their suggested correlation coefficients. However, it is relatively lower than correlation coefficients given by Khandelwal and Singh (2009), Kurtulus et al. (2011a), Sharma and Singh (2008). Our relationship between Is (50) and $\mathrm{V}_{\mathrm{p}}$ is similar to relationships given by Kurtulus et al. (2010), Kurtulus et al. (2011a), Kurtulus et al. (2011b), but its correlation coefficient $\left(R^{2}=0.88\right)$ is lower than that given by Kurtulus et al. (2010), very close to that of others. Relation between RN and $V_{p}$ is similar to relationship proposed by Kurtulus et al. (2010), however, its correlation $\left(\mathrm{R}^{2}=0.80\right)$ is higher than their suggested correlation.

\section{Conclusions}

In this study, the physico-mechanical properties including P-wave velocity, dry unit weight, uniaxial compressive strength, point load index, indirect tensile strength, effective porosity, and Schmidt hardness of the intact rocks were determined in the laboratory. The test results were interpreted statistically and reasonable good relationships were determined with P-wave velocity (ranging between 1890.0 and $6340.0 \mathrm{~m} / \mathrm{s}$ ) to the physico-mechanical properties. This result denotes that P-wave velocities could be used in determination of the physico-mechanical properties of intact rocks. 


\section{References}

ASTM (1986a) Standard test method of unconfined compressive strength of intact rock core specimens. ASTM Publication

ASTM (1986b) Standard test method of unconfined compressive strength of intact rock core specimens. D2938

ASTM (2001) Standard practice for preparing rock core specimens and determining dimensional and shape tolerances, American Society for Testing and Materials, D4543

ASTM (2005) Standard test method for cyclic (Reversed) load test for shear resistance of walls for buildings. Annual book of ASTM standards. ASTM, West Conshohocken

ASTM D5873 (2014) Standard test method for determination of rock hardness by Rebound Hammer Method, American Society for testing and material

Boadu FK (2000) Predicting the transport properties of fractured rocks from seismic information: numerical experiments. J Appl Geophys 44:103-113

Cobanglu I, Celik S (2008) Estimation of uniaxial compressive strength from point load strength, Schmidt hardness and P-wave velocity. Bull Eng Geol Environ 67:491-498

Entwisle DC, Hobbs PR, Jones NLD, Gunn D, Raines MG (2005) The relationships between effective porosity, uniaxial compressive strength and sonic velocity of intact Borrowdale volcanic group core samples from Sellafield. Geotech Geol Eng 23:793-809

Gaviglio P (1989) Longitudinal waves propagation in a limestone: the relationship between velocity and density. Rock Mech Rock Eng 22:299-306

Inoue M, Ohomi M (1981) Relation between uniaxial compressive strength and elastic wave velocity of softrock. In: Proceedings of the International Symposium Weak Rock, Tokyo, pp 9-13

ISRM (1978) Suggested methods for determining tensile strength of rock materials. Int J Rock Mech Min Sci Geomech Abstr 15:101-103

ISRM (1981) Suggested method for rock characterisation, testing and monitoring. Int J Rock Mech Min Sci Geomech Abst 18(6):109

ISRM (1987) Rock characterization suggested method. Testing and monitoring. Pergamon Press, London

ISRM (2007) In: Ulusay R and Hudson JA (eds) The complete ISRM suggested methods for rock characterization, testing and monitoring: 1974-2006, Kozan Ofset Matbaacilik, Ankara

Kahraman S (2001a) A correlation between P-wave velocity, number of joints and Schmidt hammer rebound number. Int J Rock Mech Min Sci 38:729-733

Kahraman S (2001b) Evaluation of simple methods for assessing the uniaxial compressive strength of rock. Int J Rock Mech Min Sci 38:981-994

Kahraman S (2002) Estimating the direct P-wave velocity value of intact rock from indirect laboratory measurements. Int J Rock Mech Min Sci 39:101-104

Khandelwal M, Ranjith PG (2010) Correlating index properties of rocks with P-wave measurements. J Appl Geophys 71:1-5

Khandelwal M, Singh TN (2009) Correlating static properties of coal measures rocks with P-wavevelocity. Int J Coal Geol 79:55-60

Kurtulus C, Irmak TS, Sertcelik I (2010) Physical and mechanical properties of Gokceada: Imbroz (NE AegeanSea) Island andesites. Bull Eng Geo Environ 69:321-324

Kurtulus C, Bozkurt A, Endes H (2011a) Physical and mechanical properties of serpentinized ultrabasic rocks in NW Turkey. Pure Appl Geophys. doi:10.1007/s00024-011-0394-Z

Kurtulus C, Bozkurt A, Endes H, Koc S (2011b). Seismic wave velocity and anisotropy of Devonian limestones, Nw Turkey, 6th Congress of Balkan Geophysical Society, Budapest, Hungary, October, 2011

Moradian ZA, Behnia M (2009) Predicting the uniaxial compressive strength and static Young's modulus of intact sedimentary rocks using the ultrasonic test. Int J Geomech 9:1-14

Ozkahraman HT, Selver R, Isık EC (2004) Determination of the thermal conductivity of rock from P-wave velocity. Int J Rock Mech Min Sci 41:703-708

Sharma PK, Singh TN (2008) A correlation between P-wave velocity, impact strength index, slake durability index and uniaxial compressive strength. Bull Eng Geol Environ 67:17-22

Smorodinov MI, Motovilov EA, Volvov VA (1970) Determinations of correlation relationships between strength and some physical characteristics of rocks. In: Proceedings of the second congress of the international society for rock mechanics, Vol. 2. Belgrade, pp 35-37

TUBITAK (2010) Geology map of Kocaeli Province, The Scientific and Technological Research Council of Turkey and Kocaeli Metropolitan Municipality Department Soil and Earthquake Analysis Documents

Yasar E, Erdogan Y (2004) Correlating sound velocity with the density, compressive strength and Young's modulus of carbonate rocks. Int J Rock Mech Min Sci 41:871-875 